\title{
The Reason Analysis and Countermeasure Discussion on the Current Poor Innovative Education in our Colleges and Universities
}

\author{
Wang Ke \\ School of Economy and Management \\ Shenyang Aerospace University \\ Shenyang City, China
}

\begin{abstract}
Along with the development of the times and the progress of the society, people's demand for education is also in constant ascension, which requires many colleges to struggle to do a good job of the education innovation. Meanwhile, education innovation is also the necessary path to the future education. But for now, the innovative education is still in its infancy, without rich previous experience and with lots of shortcomings and deficiencies. The road to innovative education is very difficult. In combination with the practical situation of current education, the paper made in-depth exploration and research on the main reasons of poor innovative education in many colleges and universities, and put forward several suggestions specifically, hoping to be helpful for the colleges and universities on the road of innovative education.
\end{abstract}

Keywords- Colleges and universities; Innovation; Education; Reason; Strategy

In recent years, along with the development of science and technology, knowledge economy is gradually recognized by people, and people pay more attention to the development of knowledge. In order to adapt to the trend of the times, colleges and universities begin to reform and innovate, aiming to change the traditional inculcating method into the innovative teaching mode emphasizing innovation spirit and innovation ability. However, the construction of innovation education doesn't keep pace with the times, and the problem of lag and insufficiency exists in all aspects. According to the survey of "evaluation on the college students' innovative educational thought and educational ideas" from 20 colleges and universities in $2004,92.76 \%$ of the colleges and universities embodied the thought of innovation education, but only $3.3 \%$ of the colleges and universities implemented the innovative quality assessment activities. According to the data, it's concluded that most areas in China had begun to pay attention to the education innovation, but there was no real improvement on the innovative education; the facilities and strategies are incomplete. Compared with the developed countries, there is still a big gap in the aspects such as innovative education investment, innovative education management, innovative education achievement, what's more, it can't meet the development demands of current college innovative education, which causes a certain influence on the sustainability of the innovative education in colleges and universities.

\section{EXPLORATION ON THE REASON OF INSUFFICIENT INNOVATIVE EDUCATION OF COLLEGES AND UNIVERSITIES}

There are many drawbacks for current innovative education in colleges and universities, such as insufficient funds due to less investment on innovative education, not high proportion of students participating in the innovative education, not sound innovative education mechanism, fewer innovative education base, etc. To analyze from the source, it can be divided into subjective and objective reasons.

\section{A. The subjective reasons of insufficient innovative education in colleges and universities}

1) influence of traditional ideology

Students grew up under the influence of examoriented education, edified by backward thought of teacher's dignity, and were used to acquiring knowledge by inculcating teaching. However, in the long run, students can not only become dependent, but also be hindered for the learning initiative and enthusiasm. The learning purpose of part of the students is wrong; they believe that entering a university will be easy for them to find a job, offered with high salaries and guaranteed in this life. The attitude leads them to live their college lives mechanically, wait for the Graduation Certificate and Degree Certificate, and be unwilling to make scientific research innovation.

2) Be fear of taking a risk

In numerous innovative research projects and subjects, most of them come with certain risks, which may be life risk or academic risk involved. One of the major causes for lots of college students not daring to make innovative research is that much efforts put into the innovative research may not receive good results and maybe the paper can't be passed, most seriously, the students can't graduate on time. Certainly, the subjective reasons of college students should also not be ignored, thus they can't and dare not to make innovative research; college students suffer psychological and ideological resistance to the innovative education from the source, and it's hard to implement. 
3) The degree of recognition for innovative education from the leaders is not high enough

The leaders play an important role in the innovative education; they are not only the policy makers, but also the pacemakers of the reform. Leaders should actively correct the understanding of innovative education, earnestly implement the strategy of innovative education, make the innovative education as the emphasis of each leadership, especially for the grass-roots leaders, whose understanding and level of enforcement will directly affect the results and degree of the implementation for innovative education.

B. The objective reasons for insufficient innovative education in colleges and universities

1) The hardware construction investment for innovative education is insufficient

The hardware facilities for innovative education mainly include innovative education lab, innovative educational base in and around the school, multimedia for innovative education, etc. The insufficient investment for education will directly lead to the insufficient construction funds for hardware construction funds, and the equipment for innovative experiment will be incomplete; many creative ideas from the students can't be tested by the actual experiment, which to a certain extent hinders the rapid development of innovative education.

2) The incomplete systems related with innovative education

The innovative education in our country is still in its infancy. Some schools positively responded to the calls, and established many systems related with innovative education. However, these are far from being enough to keep pace with the times for the innovative education. The strict regulatory system, strict examination system for innovative education and well-established education system are all necessary for the rapid development of education on the innovative road. Schools should actively develop and improve systems, and make up the defects.

All in all, the subjective reasons and objective reasons influence and restrain each other, and they can be seen as internal reasons and external reasons. External reasons impact the interior and accelerate the development of internal reasons; in turn, the internal reasons lead to the deterioration of external environment. The students can easily adapt to the innovative education pattern if they haven't taken the traditional education thought; without employment pressure, students would not go to the universities blindly or with utilitarian purpose; if the students actively participate in the innovation education, learn the spirit of innovation, cultivate innovation interest, and exercise innovation ability, they can better and faster promote the improvement of the external innovation mechanism, etc. Therefore, only the harmful factors of the subjective and objective parts are all solved, the innovation education can be truly implemented.

\section{SEVERAL CONSIDERATIONS AND SUGGESTIONS FOR IMPROVING INNOVATIVE EDUCATION IN COLLEGES AND UNIVERSITIES}

In recent years, the colleges and universities take the innovative talents as the most important thing in the education and teaching, actively explore and establish innovative education system, and actively explore the path of cultivating innovative talents. However, there are some shortcomings and deficiencies in the specific process:

A. improve the conditions of innovative education through multiple pathways

\section{1) Improve teaching staff building through investment introduction}

China is the most populous country in developing countries, and the education system to be established is also the largest in the world. To break through bottleneck of current college education, China faces many problems, and the insufficient funds input is the main challenge on the road of college innovative education. In terms of current situation, besides the increasing investment from the government, each college should actively broaden the financing channels in order to provide fund guarantee for the construction and development of college innovative education, and provide material guarantee for the cultivation of innovative talents. Moreover, the high-level teaching talents fund should be set up with the purpose of quality promotion for teaching staffs, high-level talents introduction and improvement of their working conditions.

\section{2) Strengthen the construction of library materials}

Books and reference materials are the source and power for the cultivation of innovative talents and the development of innovative education as well as the important channel for innovative talents to acquire resources and knowledge. College is the place of teaching and educating, and be known as the database for books and reference materials. Therefore, in order to further speed up the pace of innovation education, colleges and universities should actively expand the collection of books, and improve the hardware condition of books and materials.

\section{3) Strengthen the construction of campus} network information

The information is increasingly developed nowadays; if you have the advantage of information, there is already half success. Therefore, the network information plays a vital role in the development of innovative education. The network information can not only broaden the horizon of students and timely access cutting-edge knowledge, but also effectively enhance the professional quality of talents and train their innovation ability. Therefore, colleges should actively strengthen the construction of information network and improve the service function of information network for scientific research and teaching. 
B. improve the content of innovative education from the aspect of theory teaching and practical teaching

\section{1) Theory teaching}

In theory teaching, colleges should offer selective innovative courses and implement research-style teaching pattern to cultivate their innovative consciousness. Besides, colleges should guide the students for innovative thinking and ideas as well as provide effective space and time for innovation, build equal and relaxed academic environment, and the proportion of inquiry-based homework. The selective innovative courses opened now include innovative thinking, innovative principle, innovative skills and so on. To further expand these courses and then form the selective courses module for innovative education, which can not only arouse enough understanding for students and provide sufficient guarantee for their innovation, but also be in favor of the continuous accumulation of academic and innovative knowledge.

\section{2) Practical teaching}

Of course, in addition to theoretical courses, students will spend a lot of time in the laboratory. As practical teaching, students not only make simple experiments in the laboratory, but schools should also set the practical teaching links, such as internship, course design and military skills training in order to establish the perfect practical teaching system from shallow to deep, from junior to senior, from inside to outside, and from easy to hard. In addition, schools should also actively encourage students to self-design, self-study, and combine the internship and graduation project with actual production. The schools can also flexibly use the modern information platform, and add innovative experimental projects in view of the actual situation, such as the research innovative experiment designed by the teachers based on the teaching content, research innovative experiment transformed by the research products of teachers and developed experimental projects by the home-made equipment. Moreover, students should also be positive to participate in extracurricular practical teaching, student can choose the specified amount of experiments according to the added experimental projects and experimental curriculum requirement. Meanwhile, students can prepare the lessons, do the experiment or answer questions in the lab.

\section{Gradually improve innovative education management and system}

\section{1) Establish the mechanism that is in favor of the construction of teaching staffs for innovative education}

The good faculty is the premise and key to improve innovative education, so colleges and universities should start from the actual situation, cultivate a batch of teaching talents that conform to the schools and the society, under the principle of doing certain things but not doing everything. In the construction of teams, schools should be practical and realistic, not be exaggerated, and not propagate that they have worldclass teaching talents. Certainly, the world-class colleges are very good, especially the academicians and Yangtze River scholars are rare among them. However, such colleges are minority, so colleges should start from actual situation and do according to their abilities in terms of faculty construction.

2) Establish efficient and reasonable
employment mechanism for innovative
education

In the development of innovative education, schools should focus on the people-oriented principle, create good and equal academic atmosphere, actively cultivate excellent teachers, and try to do a good job of hiring outstanding teachers. Through external hiring and internal training, schools can cultivate some young leaders with innovative potential and ability so as to make some subjects reach the advanced world standard and drive the development of other subjects.

Many colleges and universities should be based on the actual situation on the path of innovation education. The innovative education is different from the traditional education, so it will have certain impacts on the campus management with strict system. Certainly, innovation maybe submerged in the traditional and inherent pattern. Therefore, schools should try to create the relaxed atmosphere, give light and free management, which will lay good foundation for innovation education.

\section{CONCLUSION}

With the development of the times and the progress of the society, people have increasing demand for education, so many colleges and universities should try to do a good job of education innovation. After all, education innovation will be the necessary experience for our future education. But for now, the innovation education is still in its infancy; it has no previous experience, and has lots of shortcomings and deficiencies. The road of education innovation is full of challenges. Colleges and universities should take active measures, improve the condition of innovative education through many ways, modify the content for innovative education by theoretical and practical teaching, gradually perfect the management and system for innovative education, so as to realize the development of innovative education in colleges and universities.

\section{REFERENCES}

[1] Zhou Ping. Reason analysis and countermeasure exploration on insufficient innovative education in colleges and universities nowadays [J]. Modern business, 2010, 06: 75+74

[2] Zhang Maolin. Research on the construction of R\&D team in colleges and universities under the background of innovation [D]. Central China Normal University, 2011.

[3] Liao Zhihao. Research on the cultivation of innovative technology talents based on the competency model [D]. East China Normal University, 2012.

[4] Wang Xiaohui. Research on the training of individualized personnel in first-class university [D]. Central China Normal University, 2014

[5] Liu Jing. Empirical study on the effect of innovative education in local colleges and universities on the employment of college students [D] Agricultural University of Hunan, 2012.

[6] Zhou Ping. Study on the evaluation index system and application of innovative education in colleges and universities [D]. Southwest Jiaotong University, 2009.

[7] Kan Jing. Practical exploration on innovation and entrepreneurship education in colleges and universities [D] Dalian University of Technology, 2011. 
[8] Hong Zaoqing. Study on the teaching management of colleges and universities under the background of innovative education [D]. Central China Normal University, 2002.

[9] Wang Fatang, Han Xiaohui, Lu Qi. The development of foreign innovative education and enlightenment on our innovative education in colleges and universities [J]. Journal of Shandong Youth University of Political Science, 2004, 04:74-77.

[10] Yang Qinghan. Discussion on the current situation and countermeasure to the cultivation of innovative talents in colleges and universities [D]. Sichuang Normal University, 2009.

[11] Liu Enling. The innovation on inter-school cooperation and personnel training mode in colleges and universities [D]. Shandong University, 2010.

[12] Wan Qiong. The influencing factors and optimization on innovative talents cultivation in colleges and universities [D]. Nanjing University of Aeronautics and Astronautics, 2008.

[13] Wang Xingda. Study on the innovative talents cultivation mechanism of colleges and universities in Hebei province [D]. Yanshan University, 2007.
[14] Liu Xiaohong, Wenhui. The problems and countermeasures of current innovative education in colleges and universities $[\mathrm{J}]$. Forum on contemporary education(macroscopic education research), 2007, 07:60-61.

[15] Wang Min. Study on the construction of innovative systems in colleges and universities [D]. Hunan University, 2005.

[16] Shi Yangling. Study on the development situation and cultivation of innovation ability for college students [D]. Anhui University, 2014.

[17] Ju Pengfei. Study on the current socialism core values education in colleges and universities [D]. Shanxi University of Finance and Economics, 2014.

[18] Ma Di. Study on the people-oriented innovative education in colleges and universities [D] Qufu Normal University, 2013.

[19] Chen Yujuan. Study on the innovation and entrepreneurship education of college students [D]. Hebei Normal University, 2013.

[20] Wu Yunjiao. Study on the collaborative innovation problems in colleges and universities [D]. Nanjing Normal University, 2014. 